\title{
ENVIRONMENTAL STRATEGY OF UNIVERSITIES OF SOUTHERN BRAZIL
}

\author{
ELIS MARINA TONET MOTTA, JULIANO RODRIGUES GIMENEZ \& VANIA ELISABETE SCHNEIDER \\ University of Caxias do Sul, Brazil
}

\begin{abstract}
The incorporation of environmental issues to strategic planning, called environmental strategy, has been presented as an opportunity for organizations to effectively manage the various pressures and challenges that contemporaneity has been requiring in terms of sustainability. The number of high education institutions that highlight sustainability in their strategy have been increasing during the last few years. Some reasons for this are the increase of competition in the sector, the imposed pressure for their stakeholders and their responsibility in teaching and promoting the principles of environmental ethics and sustainable development. Based on that, this study has the goal of evaluating the environmental strategy of three community institutions of higher education in southern Brazil, based on their employees' perception. To achieve the goal, a research-diagnosis study was conducted through a structured questionnaire in a digital format, in which the measurement of respondents' opinions was performed using a Likert Scale of five points. The results were evaluated based on descriptive statistics and categorized according to the environmental strategies presented on the natural resource-based view framework. It was possible to identify that each community institution of higher education that participated in the study presented a different environmental strategy, based on natural resource-based view framework. The results also indicate that even the University that presents the most developed environmental strategy has problems in disseminating environmental information through its organizational structure, based on employees' perception.
\end{abstract}

Keywords: environmental strategy, higher education institutions, pollution prevention, product stewardship, sustainable development.

\section{INTRODUCTION}

The variety of challenges and the quickness with which they are imposed to organizations, by the market, require differentiated responses from institutions in order to ensure their sustainability [1]. Countless are the agents that influence the variability and celerity of these challenges: globalization; more demanding customers; more restrictive legal instruments; technological advancements; market fluctuations; etc. [2]-[4]. These agents, acting joint or separately, send signals to companies that it is necessary to adapt their strategies, in order to leading them to more dynamic, competitive and innovative position.

The indication that part of the current environmental scenario is a consequence of the human activities [5], [6] has been increasing the political and social pressure on companies, in order them to adopt environmental actions that decrease the negative externalities and increase the positive ones [1], [7]-[10]. Thereby, the incorporation of environmental issues to strategic planning, called environmental strategy, has been presented as an opportunity for organizations to effectively manage the various pressures and challenges that contemporaneity has been requiring in terms of sustainability.

Although the design of a clear and concise environmental strategy - which is able to connect itself with other corporative goals - is commonly associated with the sector of transformation and production of consumer goods, it has been increasingly present in other areas such services sector. In this sense, it stands out the increasing number of higher education institutions that has been emphasizing the sustainability in their strategic orientation [11]. 
There are many reasons why environmental issues are each day more present into the agenda of Brazilian High Education Managers. Some of them are: Imposed pressure by their stakeholders [12], [13]; Responsibility to teach and promote the principles of environmental ethics and sustainable development [14]; Globalization process that stimulates information exchanges; Increasing number of new institutions accredited by Brazilian Education Ministry in the last decade, influencing the competition in the sector [15].

Considering the exposed arguments, this study has the aim to evaluate the environmental strategy of three community institutions of higher education (ICES, in Portuguese), based on their employees' perception (teacher and administrative staff). The method consisted on the application of an online questionnaire and the evaluation of the answers based on descriptive statistic. The results were categorized according the environmental strategies presented on the framework natural resource-based view (NRBW) [16].

\section{ENVIRONMENTAL STRATEGY}

The pressure on organizations to incorporate environmental practices into their daily activities has gradually increased over the last few years [10]. For this reason, the ability with which companies manage their environmental performance has emerged as a strategic issue [17], so that the subject has getting space on companies' planning agenda.

The environmental strategy of a company is defined as the set of deliberations that integrate environmental and corporate goals. It reflects the degree with which environmental issues are connected to organization strategic planning [18]. In this context, the perception of managers regarding environmental variables must evolve to a full business context of threatening and opportunities that, at last, may dictates which competitive position a company must adopt to survive into the market [19].

For some many authors, those organizations that are capable to incorporate environmental issues into their corporate strategies own a valuable resource that positively affect their performance [8], [9], [20]-[26]. On the other hand, some studies are not able to find a positive impact on financial performance considering the same condition [27]-[31]. These results depend on variables which correlations are not well known yet, so that new studies in this fieldwork are needed.

Table 1: NRBW summary [35].

\begin{tabular}{|c|c|c|c|}
\hline & Pollution prevention & Product stewardship & Sustainable development \\
\hline Goal & $\begin{array}{l}\text { Minimize costs; } \\
\text { Maximize profit; } \\
\text { Focus on operational } \\
\text { actions. }\end{array}$ & $\begin{array}{l}\text { Minimize costs; } \\
\text { Maximize profit; } \\
\text { Focus on product life } \\
\text { cycle. }\end{array}$ & $\begin{array}{l}\text { Minimize costs; } \\
\text { Maximize profit; } \\
\text { Focus on technological and/or } \\
\text { processual innovation. }\end{array}$ \\
\hline Method & $\begin{array}{l}\text { Organize and replace } \\
\text { materials; } \\
\text { Recycling; } \\
\text { Innovation on } \\
\text { production process. }\end{array}$ & $\begin{array}{l}\text { Integrate stakeholders' } \\
\text { views into the design } \\
\text { and product } \\
\text { stewardship. }\end{array}$ & $\begin{array}{l}\text { Integrate stakeholders' views } \\
\text { into the organizational } \\
\text { structure. }\end{array}$ \\
\hline Focus & $\begin{array}{l}\text { Production process; } \\
\text { Logistic operations. }\end{array}$ & $\begin{array}{l}\text { Production process; } \\
\text { Logistic operations; } \\
\text { Product engineering. }\end{array}$ & Brand and image. \\
\hline Result & $\begin{array}{l}\text { Decrease of operational } \\
\text { costs due to } \\
\text { implementation of } \\
\text { continuous } \\
\text { improvement } \\
\text { programs. }\end{array}$ & $\begin{array}{l}\text { Decrease of operational } \\
\text { costs and increase of } \\
\text { profitability due to } \\
\text { anticipation in } \\
\text { occupying market } \\
\text { niches. }\end{array}$ & $\begin{array}{l}\text { Decrease of operational costs } \\
\text { and increase of profitability } \\
\text { due to anticipation in } \\
\text { occupying market niches and } \\
\text { brand and image valorisation. }\end{array}$ \\
\hline
\end{tabular}


Considering this gap, the framework called natural resource-based view (NRBW) [16] was developed based on resource based-view (RBW) framework [32], aiming to evaluate the environmental strategy adopted by companies to create sustainable competitive advantages [33]. This framework was also developed to connect the environmental challenges to the resources' operationalization, since in several models there is a disconnection between the natural environment and that where organizations are inserted [34].

The NRBW model defines three kinds of exclusive strategic capabilities: pollution prevention, product stewardship and sustainable development. They have different leadership forces, which are built upon different resources and capabilities and generate different sources of competitive advantages [33]. Table 1 summaries the main information regarding to NRBW framework and its three exclusive strategic capabilities.

\section{MATERIAL AND METHOD}

The current study is characterized as a survey diagnostic [36] and its goal has a descriptive nature [37], since tend to present trends for the interest group instead of definitive answers. Has quantitative nature, since it uses quantification techniques for data collect and treatment [38].

\subsection{Community Institutions of Higher Education}

The Community Institutions of Higher Education (ICES, in Portuguese) from Brazil are nonprofit organizations with a strong social vocation, which develop activities essentially linked to teaching and researching [39]. The emergence of these institutions is connected to social mobilization. In the absence of the State, some social groups identified the need for welleducated human resource to enable economic development of the region. The ICES were born from the organization and articulation of these societal groups in meeting such demand [40]. The ICES must have, minimally, the following characteristics [41], [42]:

- Maintainer established as a private association or foundation.

- Patrimony belonging to civil society and local public authority.

- Board formed by representatives from society, public authorities and academic community.

- Non-profit.

- Democratic process to elect teachers that will work on strategic level.

The ICES were chosen as a study case due the initial hypothesis that considering the social orientation they would suffer higher pressure from their stakeholders to be a sustainability model. Table 2 synthesises the main relevant information regarding to the ICES that participated in the current study.

\subsection{Sample unit}

The research population was delimited based on convenience criteria [39]. Three community institutions of higher education (ICES, in Portuguese) from southern Brazil compose it. The sample unit from each Institution - that represents the number of employees that should answer the questionnaire based on a reliability level and sample error - was defined using eqn (1) [43].

$$
n=\frac{z_{g}^{2} \cdot \hat{p} \cdot \hat{q} \cdot N_{n}}{e^{2} \cdot(N-1)+z_{g}^{2} \cdot \hat{p} \cdot \hat{q}} \text {. }
$$


Table 2: Characterization of Community Universities [35].

\begin{tabular}{|l|l|l|l|}
\hline \multirow{2}{*}{ Characteristics } & Universities & \multicolumn{2}{|l|}{} \\
\cline { 2 - 4 } & 1 & 2 & 3 \\
\hline Students (graduate and postgraduate) & 4,080 & 9,415 & 26,374 \\
\hline Teachers & 662 & 518 & 1,153 \\
\hline Administrative staff & 209 & 591 & 1,086 \\
\hline Graduate courses & 31 & 47 & 81 \\
\hline Postgraduate courses & 2 & 7 & 15 \\
\hline Continuing education courses & 24 & 20 & 52 \\
\hline Location & $\begin{array}{l}\text { Santa Catarina } \\
\text { (SC) }\end{array}$ & \multicolumn{2}{|l|}{ Rio Grande do Sul (RS) } \\
\hline Origin of the Maintainer & Society & \multicolumn{2}{|l|}{} \\
\hline Strategic planning & $\begin{array}{l}\text { Formal, but } \\
\text { unstructured }\end{array}$ & $\begin{array}{l}\text { Formal and } \\
\text { structured }\end{array}$ & $\begin{array}{l}\text { Formal, but has } \\
\text { structural } \\
\text { problems }\end{array}$ \\
\hline
\end{tabular}

Table 3: Information to sample unit estimation.

\begin{tabular}{|l|l|l|l|}
\hline & \multicolumn{3}{l|}{ Universities } \\
\cline { 2 - 4 } & 1 & 2 & 3 \\
\hline Population size $(\mathrm{N})$ & 871 & 1,109 & 2,239 \\
\hline Sample error $(\mathrm{e})$ & \multicolumn{2}{|l|}{0.05} \\
\hline Estimative of proportion $\mathrm{p}^{\wedge}(\mathrm{p})$ & 0.50 \\
\hline Inverse probability of $\mathrm{p}^{\wedge}(\mathrm{q})$ & 0.50 \\
\hline Abscissa of normal distribution referring to the reliability level $(\mathrm{z})$ & 1.96 \\
\hline Reliability level $(\mathrm{g})$ & 0.95 & \multicolumn{3}{|l}{} \\
\hline Sample size $(\mathrm{n})$ & 146 & 136 & 164 \\
\hline
\end{tabular}

\subsection{Data collection instrument}

Relevant information for the study were obtained through a data collection instrument (questionnaire), which was reviewed by specialists and pre-tested, in order to validate it in terms of legibility, clarity, reliability and suitability.

Study participants are employees (teacher and administrative staff) from ICES, which received the instrument by email and filled it using Google docs ${ }^{\circledR}$. They have had two months to fulfil and sent the questionnaire back.

Research participants evaluated seven affirmations that represented each exclusive strategic capability from NRBW framework (pollution prevention, product stewardship and sustainable development): ESAM3, ESAM4, ESAM5, ESAM6, ESAM7, ESAM8 and ESAM9. Their opinion/knowledge were measured through a five points Likert scale, ranging from totally disagree (point 1 in the scale) to totally agree (point 5 in the scale).

\subsection{Results analysis}

The data were treated through descriptive statistic techniques, in special frequency distribution. The result analysis point which environmental strategy ICES are applying, according to the perception of their employees.

\section{RESULTS}

The main results obtained for the present study are presented as follows. 


\subsection{Adherence of study participants}

It has been verified, based on data collected, that the sample sizes for all three ICES were not hit. That happened because the answers level was lower than necessary, considering a reliability level of $95 \%$. In this sense, the information presented on Table 2 were reviewed based on obtained sample sizes and considering a new reliability level (Table 4).

Data presented in Table 4 show that the new reliability level were lower than originally estimated (95\%). Although the new results do not disqualify the present study, since all reliability levels are higher than $70 \%$, reaching $87 \%$ at University 3 , the inferences made during the subsequent items must take into account the statistic issue and the reliability of obtained data.

\subsection{Environmental strategy according NRBW}

Table 5 shows the data frequency distribution that represent the perception of ICES' employees related to different environmental situations. To facilitate data analysis and interpretation, Table 5 was converted into a heat map that visually points data concentration. Points with darker colours represent higher data concentration while points with lighter colour represent lower data concentration. The evaluation of heat map indicates which environmental strategy the ICES are using according their employees.

Data from University 1 show that the lowest data concentration is allocated at the highest point on the scale (totally agree), while data with medium and large concentrations are randomly distributed at the other points of the scale.

Based on that data collected from University 1 are not capable to explain, just by itself, which environmental strategy the institution is applying, since they do not appear to show significant trends according frequency distribution. In this sense, the evaluation of environmental strategy from University 1 should be realized using additional information, such as characteristics related to strategic planning [35].

Table 2 shows strategic planning on University 1 is incipient and informal, once does not involve neither include significant portion of its employees. In this sense and assuming that environmental strategy should be strictly linked to the institutional process of strategic planning [35], it is understood that if strategic planning has characteristics of informality the environmental strategy will also present them.

The answers from questions ESAM3 and ESAM6, which represent the strategic orientation towards pollution prevention, may support this statement. Although the solid waste management is visibly an institutional challenge - based on ESAM3 answers - it is

Table 4: New information to reliability level estimation.

\begin{tabular}{|c|c|c|c|}
\hline & \multicolumn{3}{|c|}{ Universities } \\
\hline & 1 & 2 & 3 \\
\hline Population size $(\mathrm{N})$ & 871 & 1,109 & 2,239 \\
\hline Sample error (e) & \multicolumn{3}{|l|}{0.05} \\
\hline Estimative of proportion $\mathrm{p}^{\wedge}(\mathrm{p})$ & \multicolumn{3}{|l|}{0.50} \\
\hline Inverse probability of $\mathrm{p}^{\wedge}(\mathrm{q})$ & \multicolumn{3}{|l|}{0.50} \\
\hline Abscissa of normal distribution referring to the reliability level (z) & 0.603 & 0.753 & 1.164 \\
\hline Reliability level $(\mathrm{g})$ & $72.57 \%$ & $77.34 \%$ & $87.70 \%$ \\
\hline Sample size $(n)$ & 35 & 54 & 128 \\
\hline Level of responses & $4.00 \%$ & $4.90 \%$ & $5.70 \%$ \\
\hline
\end{tabular}


Table 5: Environmental strategy evaluation.

\begin{tabular}{|c|c|c|c|c|c|c|c|}
\hline \multicolumn{8}{|c|}{ University $1(\%)$} \\
\hline \multirow{2}{*}{ [16] } & \multirow{2}{*}{ ESAM } & \multirow{2}{*}{ Mean } & \multicolumn{5}{|c|}{ Likert scale } \\
\hline & & & 1 & 2 & 3 & 4 & 5 \\
\hline \multirow{2}{*}{ PP } & 3 & 2.7391 & 22.72 & 22.72 & 27.27 & 22.72 & 4.57 \\
\hline & 6 & 2.2500 & 19.04 & 19.04 & 19.04 & 33.33 & 9.55 \\
\hline \multirow{3}{*}{ PS } & 4 & 2.9000 & 23.07 & 15.39 & 19.23 & 26.92 & 15.39 \\
\hline & 5 & 1.6667 & 28.57 & 19.04 & 19.04 & 28.57 & 4.78 \\
\hline & 7 & 1.4167 & 30.76 & 30.76 & 7.72 & 30.76 & 0.00 \\
\hline \multirow{2}{*}{ SD } & 8 & 1.6667 & 34.62 & 26.92 & 19.23 & 19.23 & 0.00 \\
\hline & 9 & 2.3333 & 19.23 & 26.92 & 19.23 & 30.76 & 3.86 \\
\hline \multicolumn{8}{|c|}{ University $2(\%)$} \\
\hline \multirow{2}{*}{ [16] } & \multirow{2}{*}{ ESAM } & \multirow{2}{*}{ Mean } & \multicolumn{5}{|c|}{ Likert scale } \\
\hline & & & 1 & 2 & 3 & 4 & 5 \\
\hline \multirow{2}{*}{ PP } & 3 & 3.9787 & 0.00 & 4.28 & 12.76 & 63.82 & 19.14 \\
\hline & 6 & 2.2500 & 0.00 & 2.64 & 26.31 & 50.00 & 21.05 \\
\hline \multirow{3}{*}{ PS } & 4 & 3.9787 & 0.00 & 2.15 & 19.14 & 57.44 & 21.27 \\
\hline & 5 & 1.6667 & 0.00 & 9.10 & 18.18 & 50.00 & 22.72 \\
\hline & 7 & 1.4167 & 0.00 & 12.50 & 33.33 & 37.50 & 16.67 \\
\hline \multirow{2}{*}{ SD } & 8 & 1.6667 & 0.00 & 11.77 & 17.65 & 49.01 & 21.57 \\
\hline & 9 & 2.3330 & 0.00 & 5.78 & 15.38 & 53.84 & 25.00 \\
\hline \multicolumn{8}{|c|}{ University $3(\%)$} \\
\hline \multirow{2}{*}{ [16] } & \multirow{2}{*}{ ESAM } & \multirow{2}{*}{ Mean } & \multicolumn{5}{|c|}{ Likert scale } \\
\hline & & & 1 & 2 & 3 & 4 & 5 \\
\hline \multirow{2}{*}{ PP } & 3 & 2.7882 & 17.64 & 27.05 & 18.82 & 31.76 & 4.73 \\
\hline & 6 & 2.9296 & 11.42 & 25.71 & 25.71 & 28.57 & 8.59 \\
\hline \multirow{3}{*}{ PS } & 4 & 3.1136 & 15.90 & 12.50 & 25.00 & 37.50 & 9.10 \\
\hline & 5 & 3.1184 & 9.21 & 17.10 & 32.89 & 34.21 & 6.59 \\
\hline & 7 & 2.6721 & 21.31 & 35.57 & 18.26 & 18.26 & 6.76 \\
\hline \multirow{2}{*}{ SD } & 8 & 2.5385 & 21.15 & 35.57 & 18.26 & 18.26 & 6.76 \\
\hline & 9 & 2.9787 & 13.84 & 21.27 & 28.71 & 25.53 & 10.65 \\
\hline
\end{tabular}

$P P$ - Pollution prevention; $P S$ - Product Stewardship; SD - Sustainable Development.

also possible to identify that the minimization of raw material use, solid waste generation and improvement of equipment efficiency are aspects present in its orientation (based on ESAM6 answers).

This demonstrates that the environmental strategy adopted by University 1 is towards oriented to pollution prevention. This orientation is usually verified in organizations that are taking the first steps in search of a strategic identity focused on the environmental issue. This result is corroborated by the evaluation of the means, which also is presented on Table 5 . The averages related to pollution prevention questions are higher than others, indicating that employees tend to agree more with this approach in comparison with the others.

The collected information for University 2 shows results that are more homogeneous. The lower data concentration is located in the lowest values of measurement scale (totally disagree and disagree), while the larger volume of data is present at the same point of the scale (agree). Mean data concentration is located both in intermediate scale value (I do not disagree, nor agree) and highest scale value (totally agree).

In this sense, it is possible to analyse that employees from University 2 agree with all environmental initiatives presented in the questionnaire, which indicates that the 
environmental strategy applied is broad and comprehensive, not only aimed at pollution prevention, but mainly at management level, with concerns on organizational brand and image. Thus, it is clear that University has an orientation towards sustainable development.

This result is corroborated by information presented on Table 2. According to that, University 2 has a formal process of strategic planning, with high degree of maturity and wide employees' participation.

Finally, the data from University 3 show an intermediary behaviour between both institutions whose results have already been presented. The lower data concentration is allocated at the highest point of the measurement scale (totally agree), the same situation pointed by University 1 . However, University 3 presents equally low concentrations in point 1 (totally disagree) for ESAM5, ESAM6 and ESAM9 and in point 2 (disagree) for ESAM4.

The higher data concentrations occur at the central points of the scale (disagree, I do not disagree, nor agree and agree), showing a lack of unanimity regarding the results, especially in comparison with data from University 2.

The identification of environmental strategy applied by University 3 will depends on the evaluation of its strategic planning process, like to University 1. Table 2 shows that University 3 has a formal strategic planning, although the employees' participation since to be inefficient. Since environmental strategy is related to strategic planning [35], the presented information indicates its orientation is more mature than University 1, although not sufficiently to be equated to University 3 . In this sense, and corroborated by data presented on Table 5, it is possible to identify that environmental strategy applied by University 3 is towards product stewardship, since its institutional focus is on offered services.

\section{CONCLUSIONS AND RECOMMENDATIONS}

The environmental issue is everyday more present into the managers' agenda all over the world. It is not a surprise that such subject is an issue even at Higher Education Institutions, whose environmental impacts from their daily activities may be compared to small urban centres [44]. Besides that, there is a view that Universities have the duty to apply what they teach and, in this context, the environmental issue gains even more significance to Brazilian Educational Institutions. The National Policy of Environmental Education requires the subject must be transversally addressed across all educational levels in the country [45]. Globalization process, exchange of teachers and students and the seek for resources to promote researches also influence the pressure undergone by Higher Education Institutions, in order to greening their activities.

Institutions must know their current environmental policy and environmental management system - whether formal or informal - and how the environmental strategy is connected, or not, to the corporate goals. However, it is important to have methods to support this evaluation, so that organizations can adapt them to their needs or even directly apply them, in order to obtain results to subsidy the managers' decision-making.

Many methods have been developed to evaluate environmental strategy at industrial sector [1], [46]-[49], nevertheless just few studies aim to evaluate how environmental issues are connected to organizational strategy in other sectors. It is on this gap that the goal of the present study is based on. The questionnaire, as a method to collect data, has been showed efficient and met the study goal. However, since a different number of questions represented each environmental strategy, the results analysis through frequency distribution was impaired. Consequently, it was necessary to evaluate the results based on complementary information (strategic planning process). Based on that, it is suggested the review of the data collection instrument, in order to guarantee equal number of questions for each environmental strategy. 
The results demonstrate that each ICES presented a different environmental strategy, based on their employees' perception and previous information about their strategic planning. The results also indicate that even the University that presents the most developed environmental strategy shows to have problems in the articulation of environmental information among its employees. If the outlined strategy is not capable of being disseminated throughout the organizational structure, it will certainly fail. In this sense, it is essential to managers to scale out new communication channels for environmental information, as well as to understand and rescale the existing ones.

Although the reliability levels for obtained samples are representative (ranging between 70 to $90 \%$, approximately), it is suggested to review data collection approach for future studies, in order to maximize the number of participants. Chen et al. [9] and Fraj, Matute \& Melero [50] show some examples of different approaches to obtain better results on data collection. Nevertheless, cultural and geographical differences as well as legal aspects must be take into account when applying different kinds of strategies.

Ucs, Univates and Uniplac.

\section{ACKNOWLEDGEMENTS}

\section{REFERENCES}

[1] López-Gamero, M.D., Molina-Azorín, J.F. \& Claver-Cortés, E., The whole relationship between environmental variables and firm performance: competitive advantage and firm resources as mediator variables. Journal of Environmental Management, 90(10), pp. 1-12, 2009.

[2] Migliato, A.L.T., Planejamento estratégico situacional aplicado à pequena empresa: estudo comparativo de casos em empresas do setor de serviços (hoteleiro) da região de Brotas - SP, p. 223, 2004. Thesis.

[3] Govindan, K. \& Cheng, T.C.E., Environmental supply chain management. Resources, Conservation and Recycling, 55(6), pp. 557-558, 2011.

[4] Martí, J.M.C. \& Seifert, R.W., Assessing the comprehensiveness of supply chain environmental strategies. Business Strategy and the Environment, 22(5), pp.339-356, 2013.

[5] Climate change 2007: mitigation of climate change; Intergovernmental Panel on Climate Change (IPCC), Cambridge University Press, Online. http://www.ipcc.ch. Accessed on: 23 Jun. 2015.

[6] Global environment outlook, GEO-4: environment for development; United Nations Environment Programme (UNEP), Progress Press Online. http://www.unnep.org/ geo/assessments/global-assessments/global-environment-outlook-4. Accessed on: 23 Jun. 2015.

[7] Sarkis, J., Gonzalez-Torre, P. \& Adenso-Diaz, B., Stakeholder pressure and the adoption of environmental practices: the mediating effect of training. Journal of Operation Management, 28(2), pp. 163-176, 2010.

[8] Gotschol, A., De Giovanni, P. \& Vinzi, V.E., Is environmental management and economically sustainable business? Journal of Environmental Management, 144(1), pp. 73-82, 2014.

[9] Chen, Y., Tang, G., Jin, J., Li, J. \& Paillé, P., Linking market orientation and environmental performance: the influence of environmental strategy, employee's environmental involvement and environmental product quality. Journal of Business Ethics, 127(2), pp. 479-500, 2015. 
[10] Betts, T.K., Wiengarten, F. \& Tadisina, S.K., Exploring the impact of stakeholder pressure on environmental management strategies at the plant level: what does industry have to do with it? Journal of Cleaner Production, 92(1), pp. 282-294, 2015.

[11] Horhota, M., Asman, J., Stratton, J.P. \& Halfacre, A.C., Identifying behavioral barriers to campus sustainability. International Journal of Sustainability in Higher Education, 15(3), pp. 343-358, 2014.

[12] Freeman, R.E., Strategic Management: a stakeholder approach, Cambridge University Press: Cambridge, p. 292, 1984.

[13] Freeman, R.E., Harrison, J.S., Wicks, A.C., Parmar, B.L. \& De Colle, S. Stakeholder Theory: the state of the art. Cambridge University Press: Cambridge, p. 362, 2010.

[14] Delakowitz, B. \& Hoffmann, A., The Hochschule Zittau/Görliz: Germany's first registered environmental management (EMAS) at an institution of higher education. International Journal of Sustainability in Higher Education, 1(1), pp. 35-47, 2000.

[15] Censo da educação superior 2012: resumo técnico; Ministério da Educação; Instituto Nacional de Estudos e Pesquisas Educacionais Anísio Teixeira, 2012, Online. http://download.inep.gov.br/download/superior/censo/2012/resumo_tecnico_censo_ educacao_superior_2012.pdf. Accessed on: 2 Dec. 2014.

[16] Hart, S.L., A natural resource-based view of the firm. The Academy of Management Review, 20(4), pp. 986-1014, 1995.

[17] Henri, J.F. \& Journeault, M., Environmental performance indicators: an empirical study of Canadian manufacturing firms. Journal of Environmental Management, 87(1), pp. 165-176, 2008.

[18] Banerjee, S.B., Corporate environmentalism: the construct and its measurement. Journal of Business Research, 55(3), pp. 177-191, 2002.

[19] De Andrade, R.O.B., Tachizawa, T. \& De Carvalho, A.B., Gestão ambiental: enfoque estratégico aplicado ao desenvolvimento sustentável. Pearson Education do Brasil: São Paulo, 2002.

[20] Porter, M.E. \& Van Der Linde, C., Toward a new conception of the environmentcompetitiveness relationship. Journal of Economic Perspectives, 9(1), pp. 97-118. 1995.

[21] Trung, D. \& Kumar, S., Resource use and waste management in Vietnam hotel industry. Journal of Cleaner Production, 13(1), pp. 109-116, 2005.

[22] Porter, M.E. \& Kramer, M.K., Strategy and society: the link between competitive advantage and corporate social responsibility. Harvard Business Review, 84(12), pp. 78-92, 2006.

[23] Aragón-Correa, J.A. \& Rubio-López, E.A., Proactive corporate environmental strategies: myths and misunderstandings. Long Range Planning, 40(3), pp. 357-381, 2007.

[24] Nakao, Y., Amano, A., Matsumura, K., Genba, K. \& Nakano, M., Relationship between environmental performance and financial performance: an empirical analysis of Japanese corporations. Business Strategy and the Environment, 16(1), pp. 106-118, 2007.

[25] Galdeano-Gómez, E., Céspedes-Lorente, J. \& Martínez-Del-Río, J., Environmental performance and spill over effects on productivity: evidence from horticultural firms. Journal of Environmental Management, 88(1), pp. 1552-1561, 2008.

[26] Wahba, H., Does the market value corporate environmental responsibility? An empirical examination. Corporate Social Responsibility and Environmental Management, 15(1), pp. 89-99, 2008. 
[27] Rao, P., Greening the supply chain: a new initiative in South East Asia. International Journal of Operations \& Production Management, 22(6), pp. 632-655, 2002.

[28] Watson, K., Klingenberg, B., Polito, T. \& Geurts, T.G., Impact of environmental management system implementation on financial performance. Management of Environmental Quality, 15(6), pp. 622-628, 2004.

[29] Wagner, M., How the reconcile environmental and economic performance to improve corporate sustainability: corporate environmental strategies in the European paper industry. Journal of Environmental Management, 76(1), pp. 105-118, 2005.

[30] Link, S. \& Naveh, E., Standardization and discretion: does the environmental standard ISO 14001 lead to performance benefits? IEEE Transaction on Engineering Management, 53(1), pp. 508-519, 2006.

[31] De Giovanni, P. \& Zaccour, G., A two-period model of closed-loop supply chain. European Journal of Operational Research, 232(1), pp. 22-40, 2014.

[32] Wernerfelt, B., A resource-based view of the firm. Strategic Management Journal, 5(2), pp. 171-180, 1984.

[33] Hart, S.L. \& Dowell, G., A natural-resource-based view of the firm fifteen years after. Journal of Management, 37(5), pp. 1464-1479, 2011.

[34] Gonçalves, R.B., Efeitos da internacionalização sobre os recursos estratégicos, p. 247, 2009. Thesis.

[35] Motta, E.M.T., Avaliação da estratégia e das práticas de gestão ambiental de instituições comunitárias de ensino superior, p. 282, 2017. Thesis.

[36] Roesch, S.M.A., Projetos de estágio e de pesquisa em administração: guia para estágios, trabalhos de conclusão, dissertações e estudos de caso. Atlas: São Paulo, 2006.

[37] Vergara, S.C., Projetos e relatórios de pesquisa em administração. Atlas: Rio de Janeiro, 2000.

[38] Richardson, R.J., Pesquisa social: métodos e técnicas. Atlas: São Paulo, 1999.

[39] Sítio de internet; Associação Brasileira das Universidades Comunitárias (ABRUC), 2015, Online. http://www.abruc.org.br. Accessed on: 25 Jul. 2015.

[40] Perobelli, M.P. \& Araujo, N.C. de., Educação e democracia entrelaçadas: a importância das Universidades Comunitárias. Universidade comunitária: essência e avaliação. Seminários dos 15 anos do Paiung. Universidade de Caxias do Sul, 2009.

[41] Lei Federal no. 12.881, de 12 de novembro de 2013, dispõe sobre a definição, qualificação, prerrogativas e finalidades das Instituições Comunitárias de Educação Superior - ICES, disciplina o Termo de Parceria e dá outras providências. Brasil, Poder Executivo, 2013, Online. http://www.planalto.gov.br/ccivil_03/_Ato2011-2014/2013/Lei/ L12881.htm. Accessed on: 25 Jul. 2015.

[42] Schmidt, J.P., O comunitário em tempos de público não estatal. Rev. Avaliação, 15(1), pp. 9-40, 2010.

[43] Fávero, L.P., Da Silva, F.L., Belfiore, P. \& Chan, B., Análise de dados: modelagem multivariada para tomada de decisões. Elsevier: Rio de Janeiro, 2009.

[44] De Conto, S.M., Gestão de resíduos em Universidades. Educs: Caxias do Sul, 2010.

[45] Lei Federal no. 9.394, de 20 de dezembro de 1996, estabelece as diretrizes e bases da educação nacional. Brasil, Poder Executivo, 1996, Online. http://www.planalto.gov.br/ ccivil03/leis/19394.htm. Accessed on: 3 Dec. 2014.

[46] Klassen, R.D. \& Whybark, D.C., Environmental management in operations: the selection of environmental technologies. Decision Sciences, 30(3), pp. 601-631, 1999. 
[47] Moreno, C.E. \& Reyes, J.F., The value of proactive environmental strategy: an empirical evaluation of the contingent approach to dynamic capabilities. Cuadernos de administración, Bogotá (Colômbia), 26(47), pp. 87-118, 2013.

[48] Ameer, R. \& Othman, R., Sustainability practices and corporate financial performance: a study based on the top global corporations. Journal of Business Ethics, 108(1), pp. 61-79, 2012.

[49] Ryszko, A., Proactive environmental strategy, technological eco-innovation and firm performance - Case of Poland. Sustainability, 8(156), pp. 1-20, 2016.

[50] Fraj, E., Matute, J. \& Melero, I., Environmental strategies and organizational competitiveness in the hotel industry: the role of learning and innovation as determinants of environmental success. Tourism Management, 1(46), pp. 30-42, 2015. 